\title{
PENGARUH SUHU RUANGAN KELAS TERHADAP KONSENTRASI BELAJAR MAHASISWA PENDIDIKAN BIOLOGI SEMESTER VII (B)
}

\author{
Ilma Nurfajriyani ${ }^{1}$, Intan $^{2}$, Qisti Fadilatussaniatun ${ }^{3}$, \\ Iwan Ridwan Yusup ${ }^{4}$, Tuti Kurniati ${ }^{5}$ \\ 1, 2, 3, 4, 5 Universitas Islam Negeri Sunan Gunung Djati; J. A. H. Nasution No. 105, \\ Cipadung, Kec. Cibiru, Kota Bandung, Jawa Barat 40614, 0227800525/022-780393 \\ e-mail: *1ilmariyani26@gmail.com, ${ }^{2}$ intansopandi36@gmail.com, \\ 3fadhillaqisti@gmail.com, 3iwanridwanyusup@uinsgd.ac.id, \\ 4tuti.kurniati@uinsgd.ac.id.
}

\begin{abstract}
ABSTRAK
Kualitas kegiatan akademik mahasiswa di ruangan kelas didominasi oleh aktifitas berfikir yang memerlukan konsentrasi tinggi. Suhu ruangan merupakan salah satu faktor penting yang harus diatur untuk menciptakan kenyamanan dalam belajar. Tujuan dari penelitian ini adalah untuk mengetahui pengaruh suhu ruangan kelas terhadap konsentrasi belajar mahasiswa. Mahasiswa peendidikan biologi semester VII (B) sebanyak 38 orang diberikan angket dalam bentuk google form, untuk mengisi beberapa pertanyaan mengenai waktu, kisaran suhu, dan faktor-faktor lain yang mempengaruhi konsentrasi ruangan. Hasil penelitian menunjukan bahwa 92,9\% menyatakan bahwa suhu berpengaruh terhadap kualitas belajar, dan 7,1\% berpendapat mungkin. Dari hasil data tersebut dianalisis ke dalam beberapa faktor lainnya seperti pengaruh suhu, pengaruh jam matakuliah dan beban matakuliah yang diambil. Suhu yang diperoleh dari pengukuran yaitu dengan kisaran suhu diruangan kelas $24^{\circ} \mathrm{C}$ dimulai dari 06.00-10.00 WIB, $32{ }^{\circ} \mathrm{C}$ dimulai dari 10.00-14.00 WIB, dan $28^{\circ} \mathrm{C}$ dimulai dari 14.00-18.00 WIB..
\end{abstract}

Kata Kunci : Suhu, konsentrasi belajar, kenyamanan kelas.

\section{PENDAHULUAN}

Pembelajaran di tingkat perguruan tinggi berbeda dengan pembelajaran di tingkat dasar dan menengah. Pada pendidikan tinggi, peserta didik yang dalam hal ini adalah mahasiswa dituntut untuk lebih mampu dalam memahami materi perkuliahan dengan konsentrasi tinggi. Konsentrasi belajar salah satunya dipengaruhi oleh faktor kondisi kelas seperti suhu ruangan. Menurut Widodo (2016: 23), suhu ruangan yang nyaman yakni berkisar antara $25-28^{\circ} \mathrm{C}$ dapat mewujudkan kenyamanan belajar mahasiswa. Berdasarkan analisis tentang kenyamanan udara terkait suhu dan kelembaban yang disusun ASHRE (American Society of Heating Refrigeration and Air-conditioning
Engineers) Standard 55-1992 dan ISO 7730 menyatakan bahwa kenyamanan suhu dapat mengekspresikan kepuasan terhadap lingkungan termalnya. Secara spesifik, terdapat batas-batas kenyamanan pada wilayah khatulistiwa dengan kisaran suhu 22,5-29 ${ }^{\circ} \mathrm{C}$.

Kondisi kelas di salah satu lingkungan universitas di daerah Kab. Bandung memiliki suhu dengan kisaran $26-30^{\circ} \mathrm{C}$ yang tidak sesuai dengan batas kenyamanan suhu ruang kelas. Kondisi tersebut diperburuk dengan tidak adanya fasilitas pendingin ruangan seperti AC (Air Conditioner), kipas angin, atau kurangnya ventilasi udara dan desain tirai penutup jendela. Jam perkuliahan dimulai sejak pukul 06:50 WIB dengan suhu awal $22^{\circ} \mathrm{C}$ hingga jam terakhir 
pada 18:00 WIB, suhu kelas biasanya naik pada siang hari sejak pukul 10:10 hingga sore kembali turun. Salah satu kelas yang menjadi objek penelitian kami mendapatkan kelas pada jam pagi hingga siang sehingga merasakan kenaikan suhu ruang kelas pada saat pembelajarannya. Kenaikan suhu pada ruang dapat mengakibatkan (1) rasa lelah yang diikuti dengan hilangnya efisiensi kerja mental dan fisik meningkat; (2) denyut jantung meningkat; (3) tekanan darah meningkat; (4) aktivitas alat pencernaan menurun; (5) suhu inti tubuh meningkat; (6) aliran darah ke kulit juga meningkat; dan (7) produksi keringat meningkat sehingga keadaan ini memicu penurunan konsentrasi mahasiswa dalam belajar terutama didukung oleh bebas SKS mata kuliah, posisi duduk, tingkat kegaduhan kelas dan cara penyapaian dosen terhadap materi kuliah (Widodo, 2016: 24).

Suhu lingkungan berpengaruh terhadap suhu tubuh dan suhu ruangan, hubungan untuk mekanisme pengendalian suhu dengan persepsi suhu lingkungan atau suhu ruangan Suhu tubuh manusia normal berkisar antara $36^{\circ} \mathrm{C}-37^{\circ} \mathrm{C}$ dan suhu tersebut akan dipertahankan sesuai dengan kemampuan tubuh. Terdapat mekanisme adaptasi apabila mengalami kepanasan temperatur di sekililingnya, yaitu dengan mengeluarkan keringat. Tanpa adanya mekanisme adaptasi, tubuh akan mengalami overheat atau pemanasan secara berlebihan dan akan membeku jika terkena suhu dingin lingkungan. (Bell dkk, 2001)

Suhu ruangan belajar (kelas) yang terlalu panas atau dingin dapat menimbulkan gangguan Ruangan yang panas atau lembab dapat menimbulkan reaksi-reaksi psikologis dari seseorang. seseorang baik itu ketidaknyamanan, cepat lelah, kurang oksigen sehingga menjadi mudah mengantuk), maupun ketidaknyamanan mental seperti munculnya berbagai macam sugesti negatif bagi penghuni ruangan tersebut. Standart yang ditetapkan oleh SNI 03-6572-2001 ada tingkatan temperatur yang nyaman untuk orang Indonesia atas tiga bagian, yaitu: a. Sejuk nyaman, antara temperatur efektif $20,5^{\circ} \mathrm{C}-22,8^{\circ} \mathrm{C}$

b. Nyaman optimal, antara temperatur efektif $22,8^{\circ} \mathrm{C}-25,8^{\circ} \mathrm{C}$

c. Hangat nyaman, antara temperatur efektif $25,8^{\circ} \mathrm{C}-27,1^{\circ} \mathrm{C}$

\section{METODE}

Metode yang digunakan dalam penelitian ini adalah deskriptif dengan pendekatan kualitatif. Penelitian deskriptif memiliki tujuan mendiskripsikan suatu fenomena/kejadian/fakta yang ada. Penelitian ini dilakukan di UIN Sunan Gunung Djati Bandung. Teknik pengambilan data yang digunakan adalah kuisioner. Kuisioner diberikan kepada 38 mahasiswa Pendidikan Biologi semester VII (B) sebagai responden. Alur penelitian yang dilakukan adalah sebagai berikut :

1. Eksplorasi Konsep dan Observasi

Pada tahap pertama yaitu eksplorasi konsep, dijelaskan bahwa berdasarkan perumusan masalah yang telah ditetapkan sebelumnya, dilakukan studi literatur mengenai konsep yang akan digunakan dalam penelitian yaitu suhu ruangan dan konsentrasi belajar. Pada tahap pertama ini juga dilakukan observasi pada mahasiswa semester VII (B) di salah satu universitas negeri. Hasil studi literatur dan observasi menghasilkan konsep dan data yang digunakan sebagai dasar dalam analisis.

2. Analisis

Pada tahap analisis dilakukan analisis variabel penelitian dengan menentukan definisi operasional masing-masing variabel dan penetapan hipotesis penelitian.

3. Pengumpulan dan Analisis Data

Pada tahap pengumpulan dan analisis data dilakukan pembuatan instrument pengukuran berupa kuesioner, pengumpulan data dan analisis data. Penyebaran data kuesioner dilakukan dengan responden mahasiswa sebanyak 38 orang. Analisis data pada penelitian ini menggunakan analisis statistik kuantitatif. Hasil dari pengumpulan data kuesioner akan diolah dan dianalisis sehingga menghasilkan kesimpulan. 


\section{Kesimpulan}

Tahap terakhir dalam penelitian ini adalah penarikan kesimpulan.

\section{HASIL DAN PEMBAHASAN}

Penelitian dilakukan pada objek 38 orang mahasiswa di salah satu universitas di daerah Kabupaten Bandung untuk mengetahui pengaruh suhu ruangan kelas terhadap konsentrasi belajar dan faktorfaktor lain yang berhubungan serta adanya fasilitas penunjang yang berdampak pada kenyamanan suasana belajar di dalam kelas. Berdasarkan survey yang telah dilakukan didapat hasil $92,9 \%$ mengatakan bahwa suhu berpengaruh terhadap kualitas belajar, dan $7,1 \%$ berpendapat mungkin. Gedung perkuliahan merupakan sebuah bangunan pendidikan. Kegiatan pendidikan adalah proses dalam belajar mengajar antara dosen sebagai pendidik dan para mahasiswa dalam ruang-ruang belajar yaitu kelas. Penting bagi ruang kelas untuk memperhatikan tingkat kenyamanan agar civitas manusia di dalamnya baik pendidik maupun mahasiswa merasa nyaman untuk melaksanakan proses belajar mengajar tersebut (Gunawan, dan Ananda, 2017: 98 - 99).

Pada dasarnya, manusia selalu berupaya untuk mencari kondisi yang nyaman pada lingkungannya. Dewasa ini hampir sebagian besar orang menghabiskan $90 \%$ waktu mereka di dalam gedung atau ruang. Oleh karena itu, pengaturan suhu menjadi sangat penting bagi kenyamanan dan kesehatan yang optimal sehingga mendukung konsentrasi penuh dalam belajar. Salah satu faktor kenyamanan proses belajar mengajar ditentukan oleh keadaan lingkungan tempat dimana proses tersebut dilakukan dalam hal ini ruangan kelas. Terdapat beberapa gangguan yang dapat ditimbulkan apabila seseorang berada di suatu ruangan yang memiliki suhu terlalu panas atau dingin. Beberapa gangguan tersebut diantaranya ialah heat cramps, heat exhaustion, heat stroke, heat rush pada suhu panas, dan chilblain, trech foot, fross bite pada suhu dingin (Sarinda, et al., 2017: 305). Ruangan yang terlalu panas atau lembab juga dapat mengganggu kondisi psikis atau mental seseorang seperti munculnya berbagai sugesti negatif serta mempengaruhi keadaan fisik yakni berkeringat, cepat lelah dan kekurangan oksigen sehingga mudah mengantuk.

Hasil observasi mendeskripsikan bahwa setengah dari jumlah objek mahasiswa merasa konsentrasi belajar terganggu pada ruangan kelas dengan kisaran suhu $32-34^{\circ} \mathrm{C}$. Sedangkan sebagian besar lainnya merasa sangat panas pada kisaran suhu ruang $30-32^{\circ} \mathrm{C}$. Hal ini sesuai dengan standar SNI 03-6572-2001 dimana suhu ruang yang nyaman berkisar pada 20 $31^{\circ} \mathrm{C}$ seperti yang dijelaskan dalam tabel berikut.

Tabel 1. Batas Kenyamanan Termal

\begin{tabular}{ll}
\hline Kondisi & Temperatur Efektif \\
\hline Sejuk nyaman & $20,5^{\circ} \mathrm{C}-22,8^{\circ} \mathrm{C}$ \\
Ambang batas & $24,0^{\circ} \mathrm{C}$ \\
Nyaman optimal & $22,8^{\circ} \mathrm{C}-25,8^{\circ} \mathrm{C}$ \\
Ambang batas & $28,0^{\circ} \mathrm{C}$ \\
Hangat nyaman & $25,8^{\circ} \mathrm{C}-27,1^{\circ} \mathrm{C}$ \\
Ambang batas & $31,0^{\circ} \mathrm{C}$ \\
\hline
\end{tabular}

(Sumber: SNI 03-6572-2001)

Selain suhu ruangan yang terlalu tinggi, terdapat beberapa faktor lain yang juga dapat mempengaruhi kenyamanan dan konsentrasi dalam belajar. Dua faktor lain yang paling utama dalam mempengaruhi konsentrasi belajar selain suhu ruangan ialah suasana belajar yang gaduh dan beban SKS mata kuliah. Tingkat kenyamanan lingkungan belajar juga mencakup lingkungan fisik, sosial, budaya, politis, dan nilai-nilai sehingga faktor suasana kelas 
yang tenang dan gaduh termasuk di dalamnya, apabila kelas terlalu berisik maka otak dan alat indera lain harus bekerja lebih berat sehingga kemampuan seseorang untuk berkonsentrasi menjadi menurun (Sarinda, et al., 2017: 306). Jumlah SKS mata kuliah yang diambil berpengaruh pada prestasi hasil belajar dan hal ini kemudian berpengaruh pada motivasi belajar sehingga apabila mahasiswa kesulitan dalam berkonsentrasi pada saat mata kuliah dengan

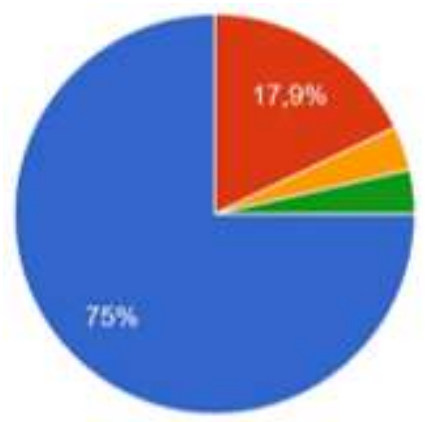

Grafik 1. Waktu Jam Belajar yang Efektif bobot SKS yang tinggi akan memberikan hasil yang kurang memuaskan dan hal ini akan berdampak pada semangat mahasiswa dalam pembelajaran selanjutnya (Elison, 1994).

Suhu ruangan juga berkaitan dengan waktu jam pelajaran atau mata kuliah yang tepat. Berikut adalah grafik hasil dari observasi terhadap jam efektif yang dilakukan saat proses pembelajaran.
Lebih dari setengah dari total seluruh mahasiswa yang dijadikan objek penelitian memilih jam efektif saat belajar di kelas adalah pada 06:50 - 10:10 WIB. Pada saat pagi hari, sinar matahari yang terpapar terasa hangat dan tidak mensuuk sehingga panas ruangan menjadi sejuk, tidak terlalu panas juga tidak terlalu lembab atau dingin. Suhu yang terlalu panas atau dingin dan tingkat kelembaban yang tinggi atau rendah dapat menyebabkan ketidaknyamanan bagi penggguna ruangan (Sarinda, et al., 2017: 306).

Upaya untuk mempertahankan atau meningkatkan konsentrasi belajar mahasiswa sebagaimana pada jam pertama kelas dimulai maka diperlukan beberapa fasilitas penunjang yang mampu memberikan kenyamanan bagi para mahasiswa. Hasil survey pada objek penelitian memberikan kalkulasi bahwa hampir seluruh mahasiswa menginginkan adanya AC (Air Conditioner) di ruang kelas sebagai alat bantu menciptakan suasana kelas yang nyaman dan menurunkan suhu ruang sehingga tidak terlalu panas dan mencapai kenyamanan termal. Fasilitas belajar secara parsial dapat berpengaruh terhadap motivasi belajar yang mampu meningkatkan konsentrasi individu di dalamnya untuk melaksanakan proses pembelajaran itu sendiri. Fasilitas tersebut dapat berupa penggunaan alat dan media pembelajaran yang bervariasi, tersedianya buku referensi yang lengkap, serta fasilitas gedung yang baik seperti luas ruangan, kondisi bangunan, sirkulasi udara yang baik, ruangan yang bersih, serta ketersediaan alatalat seperti proyektor, meja dan rak buku, termasuk AC (Jannah, 2017: 144).

Kenyamanan termal dalam suatu ruangan dapat ditentukan dari berbagai hal, termasuk diantaranya kebudayaan dan adat istiadat manusia masing-masing yang berada dalam ruangan tersebut terhadap suhu ruangan, kelembaban dan iklim karena tentu setiap orang memiliki batas yang berbeda-beda dalam bertahan pada suhu ruangan tertentu meskipun secara dominan kebanyakan manusia tidak menyukai suhu ruangan di atas $27^{\circ} \mathrm{C}$. Selian suhu ruangan dan dua hal lainnya, bau serta pencemaran udara, radiasi alam atau buatan juga bahan bangunan, warna termasuk pencahayaan ikut mempengaruhi kenyamanan secara fisik maupun fisiologis (Frick, 2008: 74) 


\section{KESIMPULAN}

Hasil penelitian menunjukan bahwa 92,9\% menyatakan bahwa suhu berpengaruh terhadap kualitas belajar, dan $7,1 \%$ berpendapat mungkin. Terdapat hubungan antara suhu dengan konsentrasi belajar, hal ini dapat terjadi karena kenaikan suhu pada ruang dapat mengakibatkan (1) rasa lelah yang diikuti dengan hilangnya efisiensi mental dan fisik meningkat; (2) denyut jantung meningkat; (3) tekanan darah meningkat; (4) aktivitas alat pencernaan menurun; (5) suhu inti tubuh meningkat; (6) aliran darah ke kulit juga meningkat; dan (7) produksi keringat meningkat oleh karena itu semakin meningkatnya suhu ruangan kelas maka konsentrasi belajar mahasiswa semakin berkurang. Suhu yang diperoleh dari pengukuran yaitu dengan kisaran suhu diruangan kelas $24^{\circ} \mathrm{C}$ dimulai dari 06.00$10.00 \mathrm{WIB}, 32^{\circ} \mathrm{C}$ dimulai dari 10.00-14.00 WIB, dan $28{ }^{\circ} \mathrm{C}$ dimulai dari 14.00-18.00 WIB.

\section{DAFTAR PUSTAKA}

Bell, P.A., Greene, T.C., Fisher, J.D., \& Baum, A. 2001. Environmental Psychology Fifth Edition. Orlando: Harcourt, Inc.

Elison. 1994. Hubungan Jumlah Sks Dengan Hasil Belajar dan Pengaruhnya Terhadap Registrasi Ulang di Lingkungan UPBJJ Palangka Raya. Unit Program Belajar Jarak Jauh Universitas Terbuka.

Frick, H. 2008. Ilmu Fisika Bangunan, Seri Konstruksi Arsitektur 8. Yogyakarta: Kanisius.
Gunawan, dan Faisal Ananda. 2017. "Aspek Kenyamanan Termal Ruang Belajar Gedung Sekolah Menengah Umum di Wilayah Kec. Mandau". Jurnal Inovtek Polbeng. Vol. 7 (2): $98-103$. ISSN 2088-6225. E-ISSN 2580-2798.

Jannah, Muzdalifatuz Zahrotul. 2017. "Pengaruh Fasilitas Belajar dan Motivasi Belajar Terhadap Prestasi Belajar Siswa Kelas V pada Mata Pelajaran Matematika di MI Bustanul Ulum Brudu Sumobito Jombang". Tesis. Malang: UIN Maulana Malik Ibrahim Malang.

Sarinda, A., Sudarti, dan Subiki. 2017. "Analisis Perubahan Suhu Ruangan Terhadap Kenyamanan Termal di Gedung 3 FKIP Universitas Jember". Jurnal Pembelajaran Fisika. Vol. 6 (3): 305-311.

SNI. 2001. Tata Cara Perancangan Sistem Ventilasi dan Pengkondisian Udara pada Bangunan Gedung. Jakarta: BSN.

Widodo, Wahyu. 2016. "Wujud Kenyamanan Belajar Siswa, Pembelajaran Menyenangkan, dan Pembelajaran Bermakna di Sekolah Dasar". Jurnal Ar-Risalah. Vol. 17 (2): $22-37$. 